\title{
眼球内力学特性評価のための新しい力学的指標*
}

\author{
木村 洋介 ${ }^{* 1}$, 金子 真 ${ }^{* 2}$, 相澤 奈帆子*3 \\ 田中 佑治 ${ }^{* 3}$, 國方 彦志 ${ }^{* 3}$, 中澤 徹 ${ }^{* 3}$
}

\section{Mechanical Characteristic Index Expressing Internal Properties of Eyeball}

\author{
Yosuke KIMURA*1, Makoto KANEKO, Naoko AIZAWA, Yuji TANAKA, Hiroshi KUNIKATA and \\ Toru NAKAZAWA \\ *1 Graduate School of Engineering, Osaka University \\ 2-1 Yamadaoka, Suita, Osaka, 565-0871, Japan
}

There is a big need for estimating internal properties of eyeball, since they shoud be closely related to eye diseases, such as detached retina. Based on this background, this paper discusses a new bio-marker expressing the mechanical characteristics of internal eyeball. For this purpose, we focus on subjects having vitreum surgery in which vitreum of subject is replaced with succedaneum. With the assistance of high speed camera, the eye deformations before and after operation are captured during air-puff impartment. Through the analysis, we found the difference between the behaviors before and after operation, especially the shape of eye ball immediately after the tip of cornea recovers. We discuss why such different behaviors happen and how we can explain the physics.

Key Words : Bio-Marker, Deformation, Non-Invasive, Mechanical Characteristics, Vitreum Operation

$$
\text { 1. は じめ に }
$$

図 1(a) は眼球の構造を示したものである.眼球体積の 8 割は硝子体 (Vitreum) で構成されており，硝子体は約 $99 \%$ 水分で残り $1 \%$ が固形成分である ${ }^{(1)}$.この硝子体は外部からの圧迫などによる機械エネルギーが加わった場 合に, 兴のエネルギーを吸収するショックアブソーバとしての物理的バリア機能や，物質の硝子体への移行・拡散 を防ぐなどの化学的バリア機能, 周囲の組織からの細胞の遊走・増殖に対してバリアとなるなどの細胞生物的バ リア機能を備えている(2). しかし，硝子体の構造や機能についてはいまだによくわかっていない部分が多くある. 兴のため硝子体ゲルの透過波長曲線を求めることや, 粘度を検証することなど硝子体について多くの研究が行わ れている(3) (6) .さらに硝子体は, 高年齢になると構造の変性・破壊によって水保持能が消失し水分子が放出され， 図 1(b)のように硝子体液を溜める空間が生じてしまう ${ }^{(7)}$. この現象は液化とよばれ，この液化が網膜剥離などの 眼疾患の原因として挙げられる ${ }^{(8)}$. 光のため硝子体の液化の進行度合いを, 外部から非侵襲で診断することがで きるようになれば眼疾患の事前予測が可能となる . 液化現象については数多く研究が報告されている ${ }^{(3)}\left(^{(9)} も の の ，\right.$ これらの研究はウサギなどの動物実験や，摘出した硝子体を対象としたものがほとんどで, ヒトに対して生体内 で (in-vivo) かつ非侵襲で行われた研究は筆者らか調べた範囲において報告されていない．

筆者らはこれまでに空気噴流を角膜表面に印加したときの角膜変形特性を調べ, 空気噴流印加時には二つの変 形特性か現れることを明らかにした ${ }^{(12)}$. 図 2 は光の二つの変形特性を示したものである.一つは眼球全体の移動 $d_{1}$ であり，もう一つは角膜頂点部の変形で眼圧に直接関与する変形 $\Delta d=d_{2}-d_{1}$ である . このうち眼球全体の移動 は, 眼球または眼球を支持する組織の変形によるものであり硝子体の機械的特性を間接的に観察できる可能性を 秘めている．この点を検証するために本研究では硝子体手術前後の角膜変形挙動に着目する．ここで，硝子体手

* 原稿受付 2012 年 11 月 22 日

*1 正員, 大阪大学大学院工学研究科（干565-0871 大阪府吹田市山田丘 2-1）

*2 正員, フェロー, 大阪大学大学院工学研究科

*3 東北大学大学院医学系研究科

E-mail: kimura@hh.mech.eng.osaka-u.ac.jp 


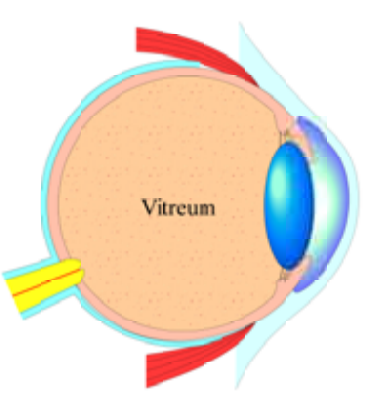

(a) Young

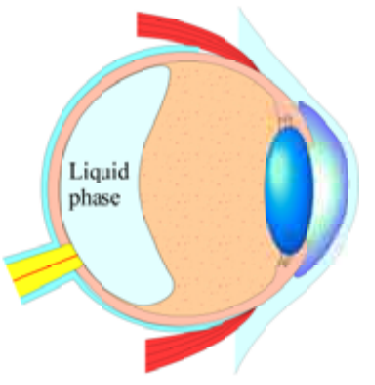

(b) Senior
Fig. 1 Structure of eyeball

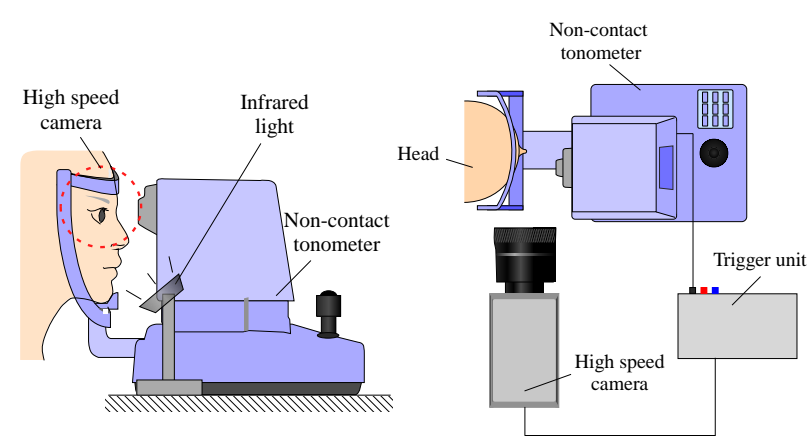

Fig. 3 Experimental system

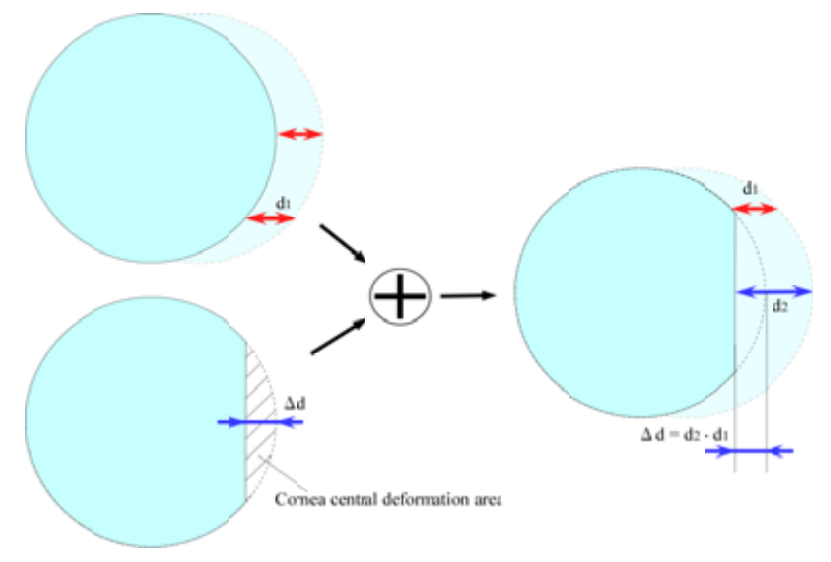

Fig. 2 Behavior of eye

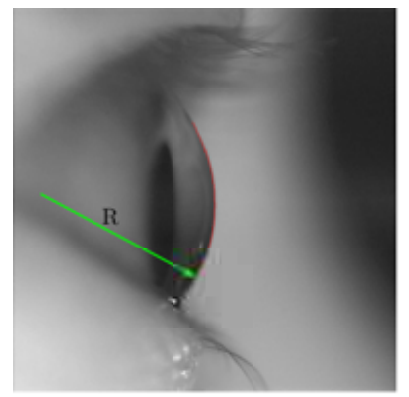

(a)Before force impartment

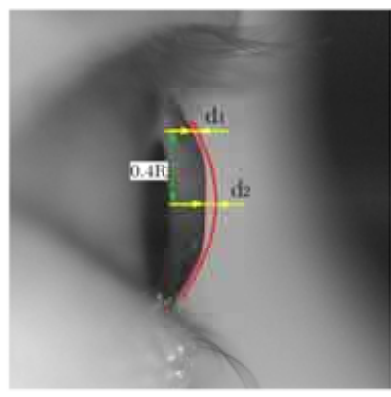

(b)After force impartment
Fig. 4 Parameters for analysis

術とは裂孔原性網膜录離や糖尿病網膜症など多くの疾患に対して行われる手術で, 液化した部分を含んだ硝子体 を切除し，代用物を注入することによって治療を行う手術である ${ }^{(1)}(10)$. 本研究では代用物としてビーエスエスプ ラス 500 眼灌流液 $0.0184 \%{ }^{(11)}$ を用いた . 硝子体手術前後に着目する最大の理由は, 手術によって硝子体を取り除 いてしまうため眼球内力学特性の変化がもっとも顕著に表れると期待できるためである . 具体的には硝子体手術 を行う患者に対して, 手術前後で空気噴流を用いた角膜変形挙動取得臨床試験 ${ }^{(12) \sim(16)}$ を行い, 光れ攵れの变形挙 動を比較する．この試験によって，手術前後で角膜中心部の変位挙動に明確な差が見られることを確認した . こ の結果は眼球形状を保持する役割がある硝子体を取り除いたことにより，眼球全体が変形しやすくなったと考え るときわめて明快に説明でき, 結果的に手術前後の角膜中心部の変位 $d_{2}$ が眼球内力学特性を評価する新たな力学 的指標となりえることを示唆した .

\section{2. 実験}

\section{$2 \cdot 1$ 実験装置}

図 3 は実験システムの側面図と上面図を示したものである . 実験システムは印加力発生系と計測系に分けられ る.印加力発生系として角膜に空気噴流を加えるために，非接触眼圧計（(株) トプコン: CT-90A) を用いる.この 非接触眼圧計には角膜中心を認識するための CCD カメラと, 空気噴流を発生するピストンが内蔵されている. 計 測系として角膜の変形挙動を撮影するために, 高速度カメラ ( (株) ナックイメージテクノロジー : MEMRECAM GX-1) とトリガーユニット（（株）ナックイメージテクノロジー：Trigger Unit N9619）を用いる.非接触眼圧計

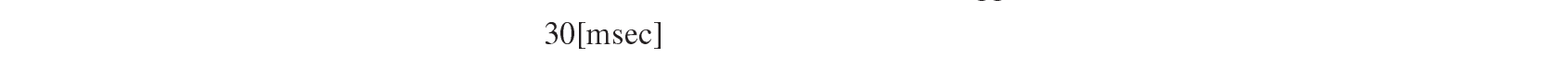
現象を捉えることはできない . 
Table 1 Subject

\begin{tabular}{|c|c|c|c|c|}
\hline Name & Age & IOP before operation & IOP after operation & Operation \\
\hline \hline Subject 1 & 68 & $11[\mathrm{mmHg}]$ & $13[\mathrm{mmHg}]$ & Vitreous surgery \\
Subject 2 & 63 & $20[\mathrm{mmHg}]$ & $18[\mathrm{mmHg}]$ & Vitreous surgery, Cataract surgery \\
Subject 3 & 63 & $13[\mathrm{mmHg}]$ & $17[\mathrm{mmHg}]$ & Vitreous surgery, Cataract surgery \\
\hline
\end{tabular}

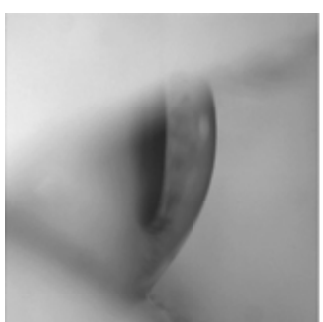

(a) $\mathrm{t}=0[\mathrm{msec}]$

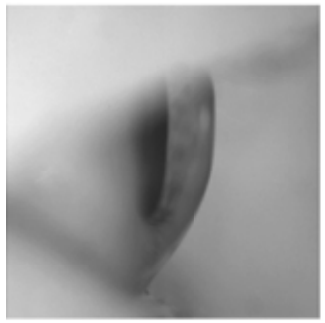

(b) $\mathrm{t}=15[\mathrm{msec}]$

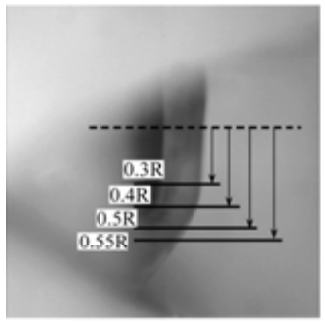

(c) $\mathrm{t}=20[\mathrm{msec}]$

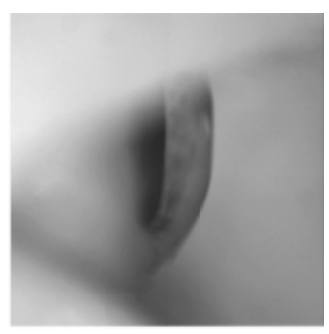

(d) $\mathrm{t}=26[\mathrm{msec}]$

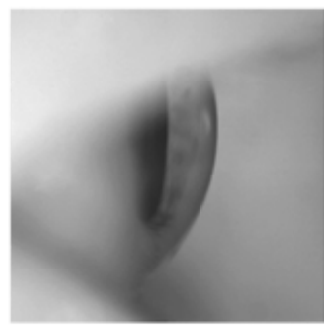

(e) $\mathrm{t}=30[\mathrm{msec}]$

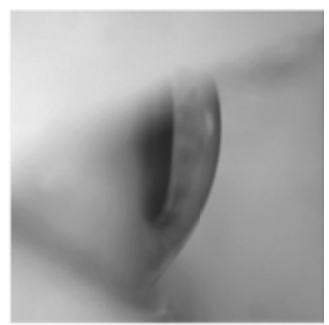

(f) $\mathrm{t}=40[\mathrm{msec}]$

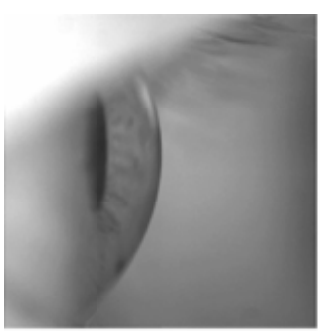

(a) $\mathrm{t}=0[\mathrm{msec}]$

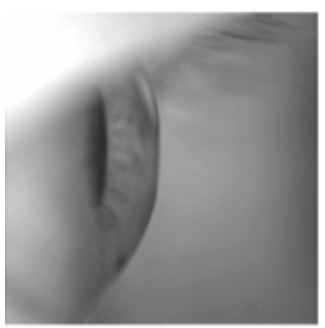

(b) $\mathrm{t}=15[\mathrm{msec}]$

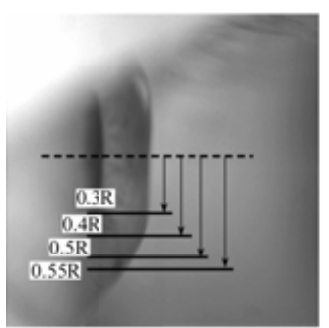

(c) $\mathrm{t}=20[\mathrm{msec}]$

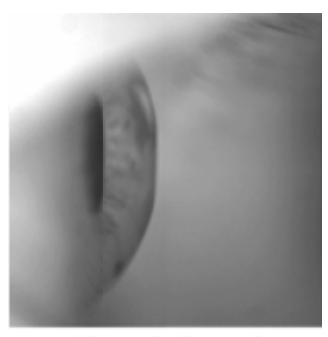

(d) $\mathrm{t}=26[\mathrm{msec}]$

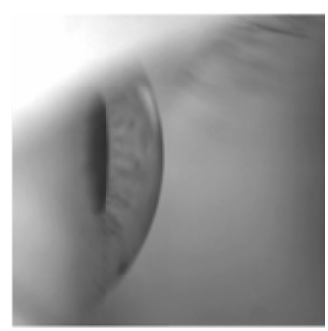

(e) $\mathrm{t}=30[\mathrm{msec}]$

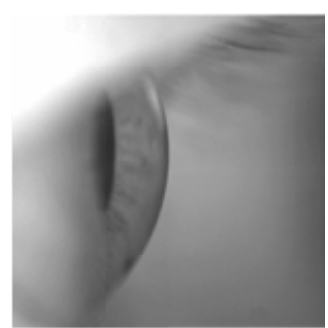

(f) $\mathrm{t}=40[\mathrm{msec}]$

Fig. 5 Deformation of eye before operation of subject 1

Fig. 6 Deformation of eye after operation of subject 1

\section{$2 \cdot 2$ 実験方法}

実験では 608[pixel]×608[pixel] サイズの画像をフレームレート 5000 [fps] で撮影する . 产の際非接触眼圧計と高 速度カメラをトリガーユニットで接続することで，眼圧計のスイッチを押すのと同時に撮影を開始する . 図 4 は 空気噴流印加時の角膜変形に関する各パラメータの幾何学的な意味を示したものである.ここで $R$ は画像から求 めた眼の近似円半径, $d_{1}, d_{2}$ は光れ光れ図 2 の $d_{1}, d_{2}$ と対応しており角膜周辺部変位, 角膜中心部変位を示し ている. 角膜周辺部の変位 $d_{1}$ は眼の近似円半径 $R$ を用いて, 角膜中心軸に平行に $0.4 R$ 離れた軸での変位を求め ている. $0.4 R$ とした理由は, 従来研究 ${ }^{(12) \sim(16)}$ のデータを参考にし, 図 2 左下に示す角膜中心部変形領域 (Cornea central deformation area) に含まれない位置で眼球全体の变形挙動を観察できると考えたためである. 実験は表 1 に示す 3 人の被験者に対して，事前に実験概要の説明を行い，倫理委員会指定の書類に同意を得たのちに手術前後 で光れ各 3 回行う.表 1 において IOP (Intraocular pressure) は眼圧值を, Operation では硝子体手術 (Vitreous surgery) のみ行うか, 白内障手術 (Cataract surgery) も同時に行うかを示している. 白内障手術とは, 水晶体を超 音波で乳化し吸引したのちに眼内レンズを挿入する手術で硝子体手術と同時に行われることが多い(7). 


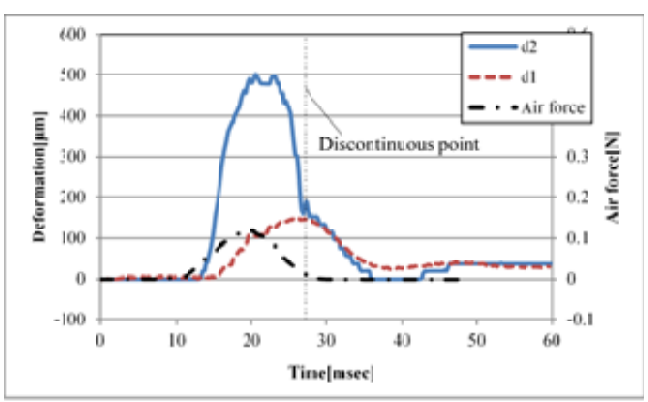

(a) Firstexperiment

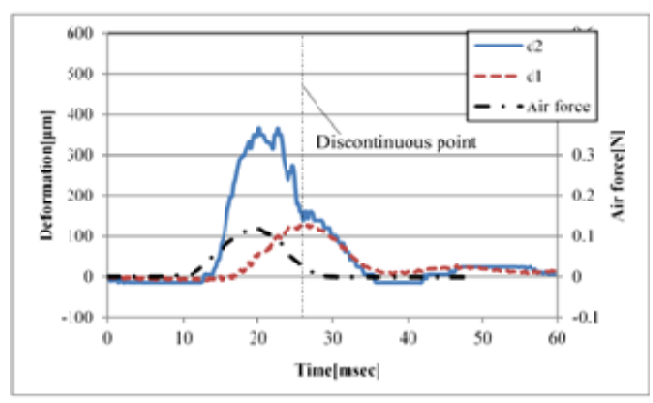

(b) Second experiment

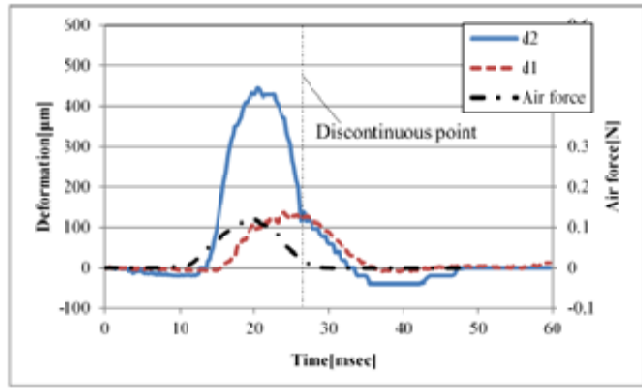

(e) Third experiment

Fig. 7 Experimental results before operation of subject 1

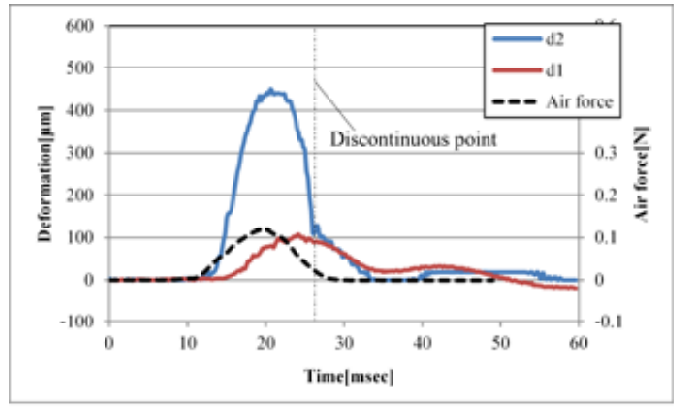

(a) Experimental result before operation of subject 2

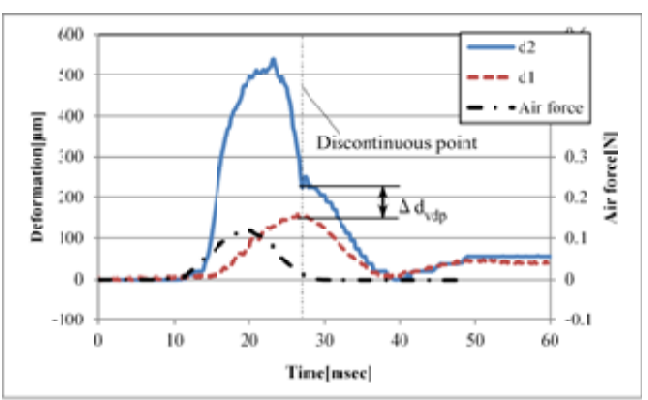

(a) First experiment

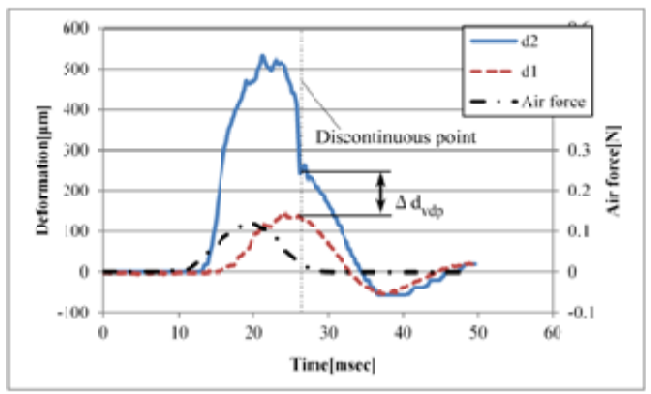

(b) Second experiment

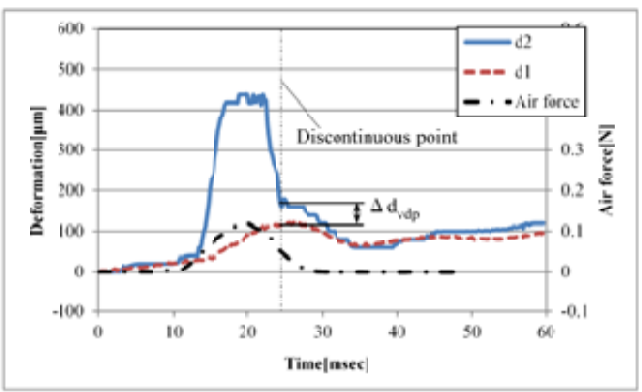

(c) Third experiment

Fig. 8 Experimental results after operation of subject 1

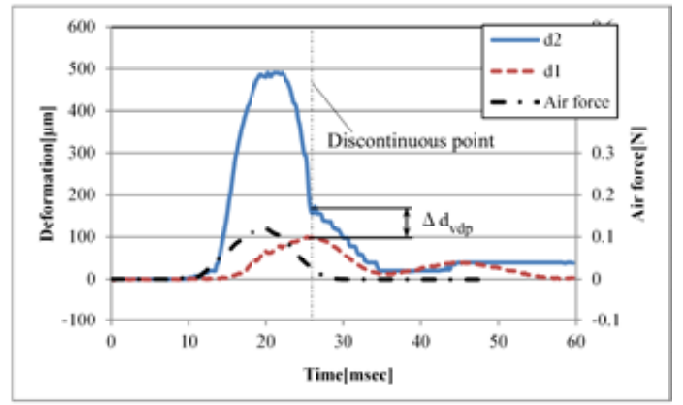

(a) Experimental result after operation of subject 2

Fig. 9 Experimental result of subject 2

\section{$2 \cdot 3$ 実験結果}

図 5 および図 6 に乥れぞれ被験者 1 の手術前後において実験で得られた画像の一例を示す.乥れぞれ変形前 $(\mathrm{t}$ $=0[\mathrm{msec}]) \rightarrow$ 変形直後 $(\mathrm{t}=15[\mathrm{msec}]) \rightarrow$ 最大変形付近 $(\mathrm{t}=20[\mathrm{msec}]) \rightarrow$ 変形回復 $(\mathrm{t}=26 \sim 40[\mathrm{msec}])$ の順に なっている.図 7 および図 8 は光れ光れ被験者 1 の手術前後の実験結果をすべて示したものである.图 7 おび 図 8 において左側の縦軸は変位量, 右側の縦軸は角膜に印加した空気噴流の力, 横軸は時間を示しており実線, 点

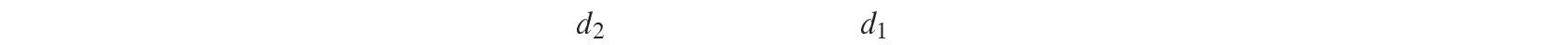
いる. 手術前後ともに角膜周辺部変位 $d_{1}$ および角膜中心部变位 $d_{2}$ は, 空気噴流が印加されてから遅れをともなっ 


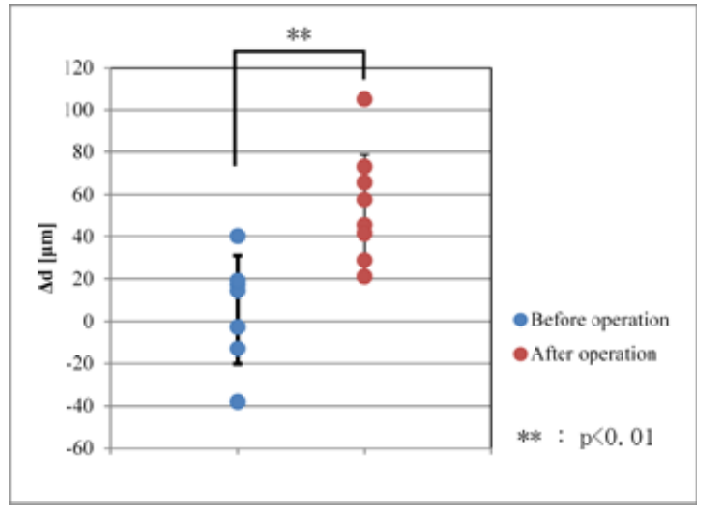

Fig. $10 \Delta d_{v d p}$ before and after operation

て変位していることがわかる .さらに, 角膜周辺部変位 $d_{1}$ は角膜中心部変位 $d_{2}$ と比較して , 立ち上がり時間に 遅れが見られることがわかる. 特に前者の遅れは眼圧が角膜変形を妨げていることに起因する ${ }^{(15)}$. 角膜中心部変 位 $d_{2}$ の $27[\mathrm{msec}]$ 付近において角膜変位の戻り速度が極端に変化していることがわかる.この点を速度不連続点 (Velocity discontinuous point) と呼ぶことにする .

手術前後の結果を比較すると速度不連続点で明確に差が見られることがわかる．手術前において，角膜周辺部 変位 $d_{1}$ と角膜中心部変位 $d_{2}$ は速度不連続点以降ほぼ一致しているのに対し, 手術後においては角膜周辺部変 位 $d_{1}$ と角膜中心部変位 $d_{2}$ の間で $100[\mu \mathrm{m}]$ 程度の差が生じていることがわかる . この速度不連続点における差を $\Delta d_{v d p}=d_{2 v d p}-d_{1 v d p}$ とする. $\Delta d_{v d p}$ が 100[ $\left.\mu \mathrm{m}\right]$ 程度現れるという点において，手術前後各 3 回すべてで同樣の傾 向がみられる .この傾向は他の 2 人の被験者にもみられる.図 9 は被験者 2 の結果の一例を示したものである.被 験者 2 と 3 は被験者 1 と異なり硝子体手術のみでなく白内障手術もしているため, 光の影響が角膜変形挙動に表れ ると予想できるが図 9 は被験者 1 と同樣の傾向を示している . 各被験者の速度不連続点における差 $\Delta d_{v d p}$ を解析し

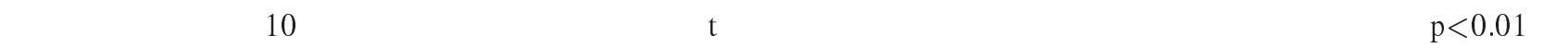
角膜変形挙動取得実験の実験精度については次章にて考察を行う.なお, 手術後の図 8(b) において 50[msec] 以降 は瞬目の影響により角膜変形を解析することが困難であったため割愛した .

\section{3. 考察}

\section{$3 \cdot 1$ 眼球の挙動}

手術前後において角膜変形挙動か変化した理由について考察する.図 11,12 は光れ光れ被験者 1 を例に，手術 前後の各時刻において眼球がどのような挙動を示すのかを推測した図である. 図 11,12 では簡単のため眼球を球 ないし楕円でモデル化しており，弚れ午れグラフの縦点線の時刻における変形挙動を示している.さらに，グラ フ中の各時刻の变位の矢印と球における矢印が対応している.

まず手術前について考える . 図 11(a) は空気噴流が角膜に印加された時刻 $(\mathrm{t}=12[\mathrm{msec}])$ で，角膜はこの時刻 ではまだ変形を生じていない . 時刻が経過し図 11(b) ( $\mathrm{t}=16[\mathrm{msec}])$ においては, 角膜のみが変形を始めているが 角膜周辺部はまだ変形が生じていない $. \mathrm{t}=20[\mathrm{msec}]$ になると図 $11(\mathrm{c})$ のように角膜周辺部変位が生じ角膜中心部 の変位が最大になる .このとき角膜周辺部も変位していることから眼球全体も移動し始めていると考えることが できる.さらに時刻が経過し $\mathrm{t}=27[\mathrm{msec}]$ 以後は, 角膜中心部変位と角膜周辺部変位がほとんど同程度であること から, 図 11(d)のように眼圧に関与する角膜頂点部の変形 $\Delta d=d_{2}-d_{1}$ は零となり眼球移動のみが生じていると考 えられる. $\mathrm{t}=40[\mathrm{msec}]$ において図 11(e)のように眼球は元の位置に戻る. 以上が手術前の角膜変形挙動に対する 考察である。

次に手術後における角膜変形挙動について考える.空気噴流が角膜に印加された時刻 $(\mathrm{t}=12[\mathrm{msec}])$ および角 膜のみが変形を始めている時刻 $(\mathrm{t}=16[\mathrm{msec}])$ については手術前と同樣である. しかし $\mathrm{t}=20[\mathrm{msec}]$ では手術後 の眼は角膜の变形 , 眼球の移動のみならず図 12(c)のように眼球か球状から棈円形状に変形していることが考えら れる.これは眼球形状を保持する役割を担っている硝子体を切除したことによって, 眼球か変形しやすくなったた 

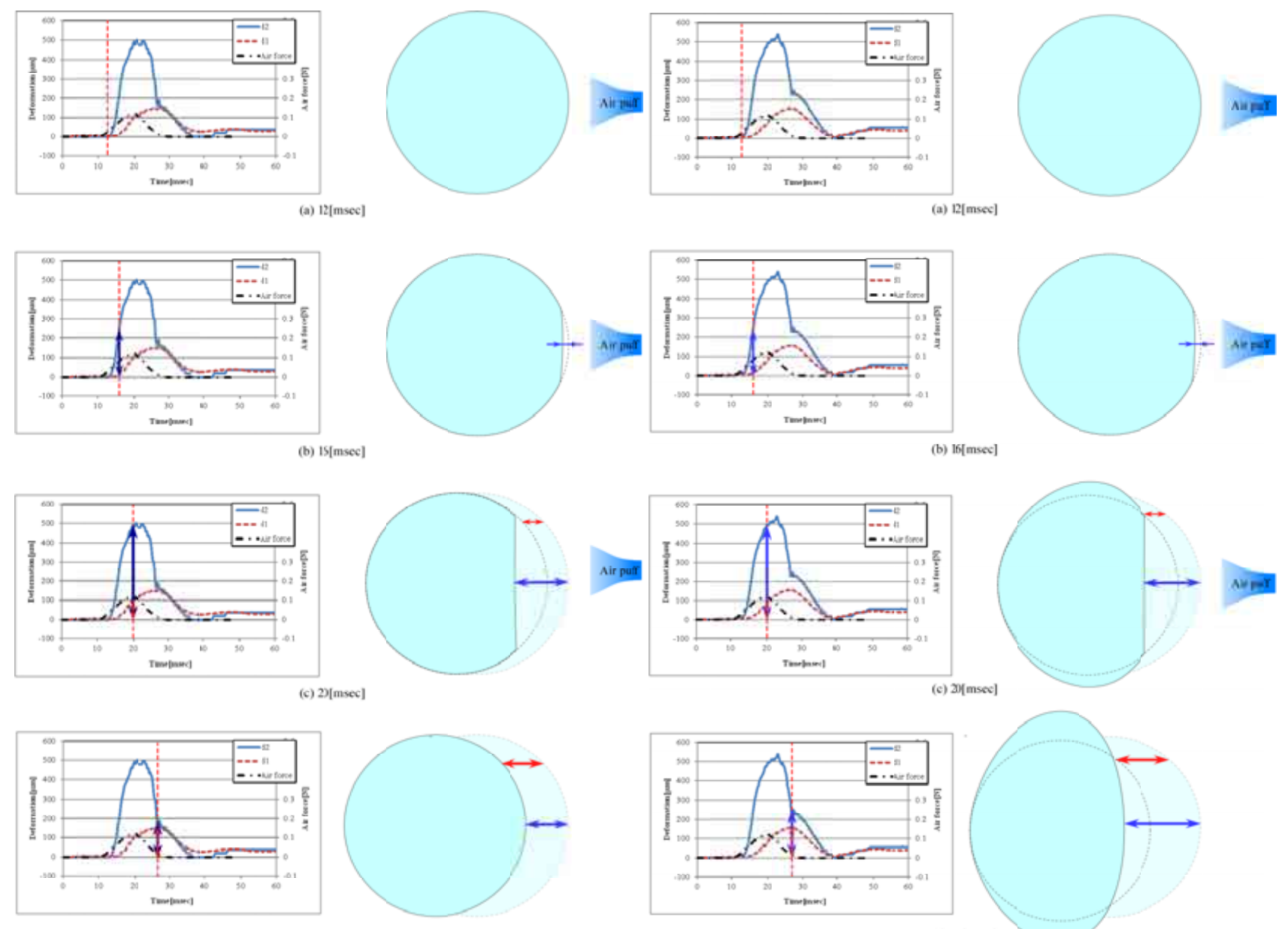

(d) $27[\mathrm{msec}]$
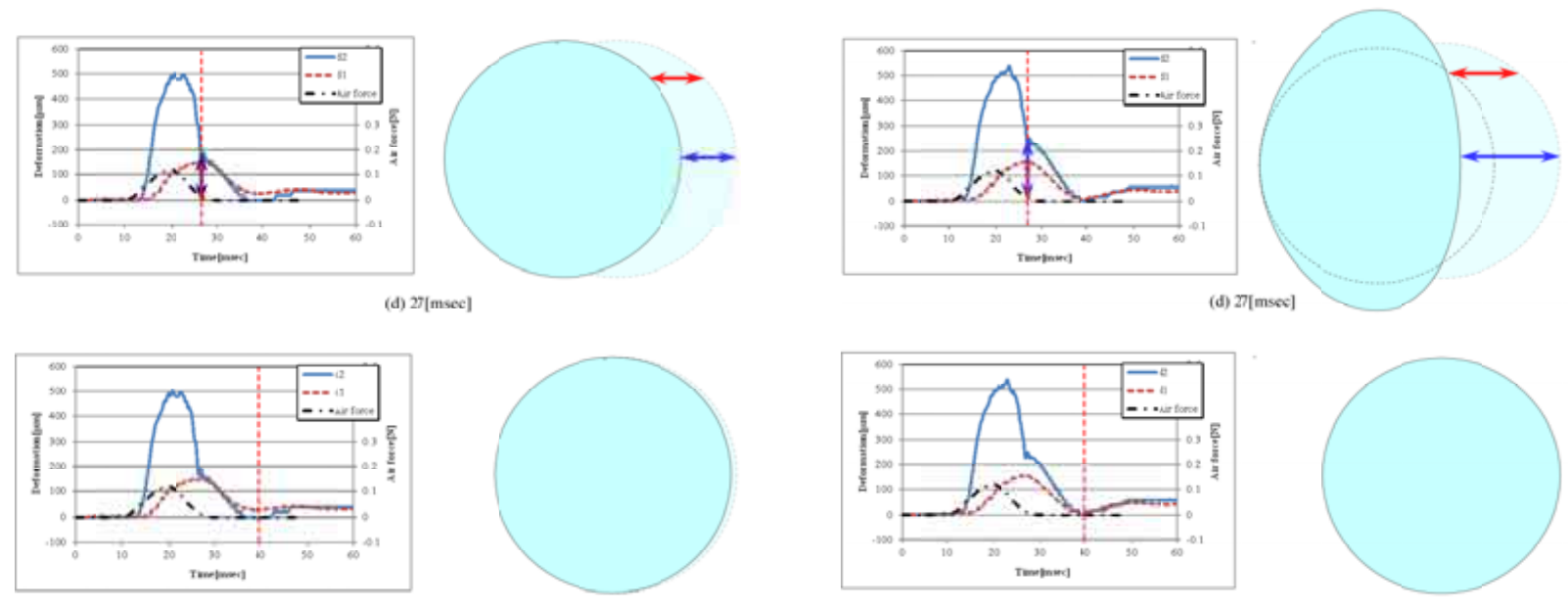

(c) 4)[msec]

Fig. 11 Behaviors before operation of subject 1
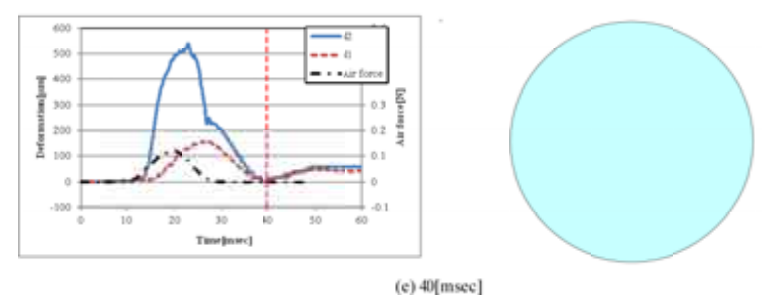

Fig. 12 Behaviors after operation of subject 1

めである $\cdot \mathrm{t}=27[\mathrm{msec}]$ になると図 12(d) のように角膜中心部はもとの形に戻るが，眼球は楕円形状になっている と考えられる.このため角膜の変形は回復しているにもかかわらず角膜中心部変位と周辺部変位に差 $\left.\Delta d\right|_{t=27 m s e c}$ が生じたと推測される $\mathrm{t}=40[\mathrm{msec}]$ では図 12(e)のように手術前と同樣眼球はほとんど元の位置に戻る .

\section{$3 \cdot 2$ 眼球変形に対する考察}

図 13 は被験者 1 の手術前後の画像に対して $0.3 R, 0.4 R, 0.5 R, 0.55 R$ の点における変位量を解析した結果である. 角膜中心部変位を点線で示し, 各点における変位を実線で示す. 図 5(c) および図 6(c) からわかるように $0.3 R$ は 角膜中心部変形領域に含まれているため, 手術前後ともに他の点と異なる挙動を示している . 图 13(a)の手術前に おいて 0.4R〜0.55R における変位挙動に差がないことから, 眼球が図 11(c)(d) の右図のような動きをしているこ とがわかる. 弚れと比較して手術後の $\mathrm{t}=27[\mathrm{msec}]$ 付近では $0.4 R$ と $0.55 R$ の変位の差が手術前よりも $30[\mu \mathrm{m}]$ 程度 大きくなっていることがわかる .これは手術前では眼球が球状を維持しているのに対して, 手術後では眼球が図 12(c)(d) のように棈円形状になったことによるものだと考えられる .つまり周辺部変位の变化から図 14 に示すよ うに手術後の眼球は球状を保っておらず楕円状に近い変形をしていることがわかる．このような眼球全体の形状 変化の代表として強度近視が挙げられる. 強度近視では $3[\mathrm{~mm}]$ 以上変形することが報告されている ${ }^{(18)}$. 今回み 


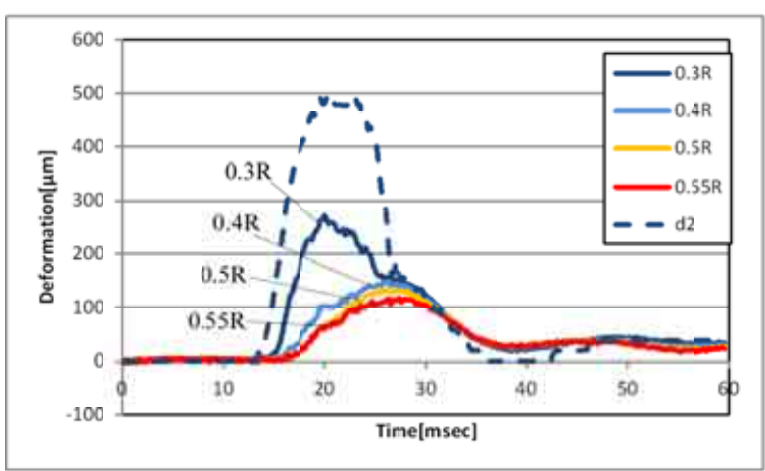

(a) Before operation

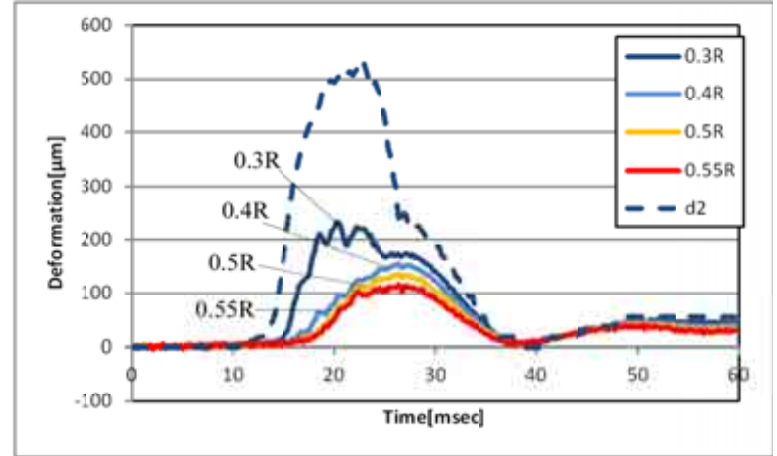

(b) After operation

Fig. 13 Deformation of $0.3 \mathrm{R} \sim 0.55 \mathrm{R}$ of subject 1

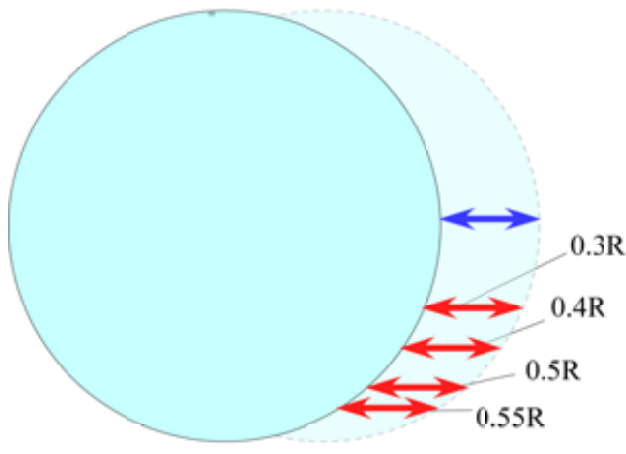

(a) Before operation

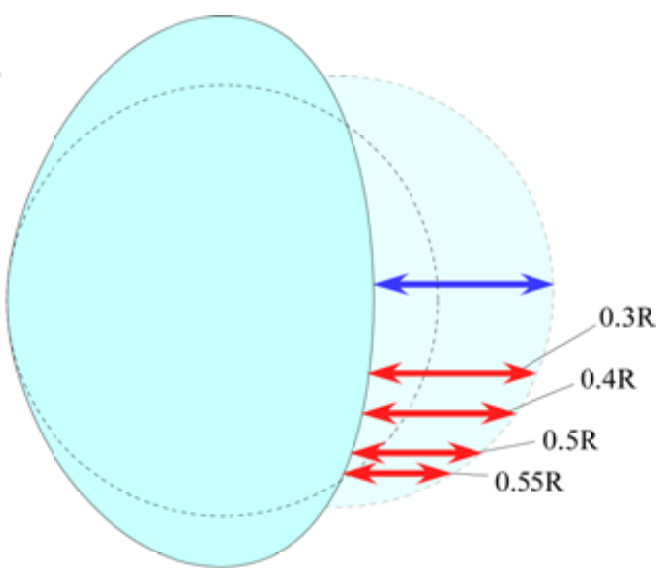

(b) After operation

Fig. 14 Deformation of discontinuous point

られた速度不連続点における角膜中心部変位と周辺部変位との差 $120[\mu \mathrm{m}]$ 程度は, これと比較して十分小さいこ とからも楕円状変形が十分に生じうる可能性があることがわかる . 外力に対して眼球の形状を保持する役割のあ る硝子体を手術で取り除いたために, 空気噴流に耐え切れず眼球全体の変形を生じるようになったと考えられ，こ の眼球全体の変形による角膜中心部と周辺部との変位差 $\left.\Delta d\right|_{t=27 m s e c}$ は眼球内力学特性を評価する新たな力学的指 標になる可能性があることがわかる .

\section{$3 \cdot 3$ 実験精度の検証}

本研究で行った角膜変形挙動取得実験の実験精度について検証を行う. 実験によって得られる画像の解像度は約 $18[\mu \mathrm{m} / \mathrm{pixel}]$ であるが, 解析では精度を高めるために角膜周辺部・中心部変位ともに 10pixel の平均值を導出して いる.しかし, 図 7 と図 8 の実験結果より 3 回の実験において挙動の傾向は同じ傾向を示しているものの, 角膜中 心部の最大変位を例に考えると $100[\mu \mathrm{m}]$ 程度のズレがあることがわかる .このズレの原因は計測や解析による誤 差も含まれているが，もつとも大きい原因として眼圧変動が挙げられる . 対象としている生体眼では脈拍, 呼吸 などにより絶えず眼圧か変動しており, 測定を行うたびに $3[\mathrm{mmHg}]$ 程度の範囲で眼圧值が変動する ${ }^{(19)(20)}$. 被験 者 1 の眼圧值が実験前と実験後で光れぞれ $11[\mathrm{mmHg}], 13[\mathrm{mmHg}]$ であったことから眼圧変動は眼圧值の $25 \%$ 程度 と非常に大きく影響することがわかる．このことが実験結果のばらつきに大きく影響すると考えられる．しかし，

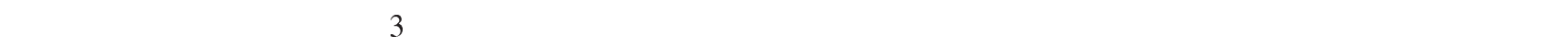
行う目的には支障はないと考えている.なお，図 8(c) の実験結果が他の実験結果と少し異なる挙動を示している のは, 撮影の初期から瞬目の影響が出たためと考えている . 瞬目が始まると瞼の圧力によって眼球が奥に移動し 始める.このことにより図 8(c) では初期段階から変位していると考えられる.ただし図 8(c) についても 28[msec] 付近で角膜中心部変位が周辺部変位よりも大きいという他の 2 回の結果と同樣の結果を示している . 


\section{4. ま と め}

本論文では硝子体手術の前後において角膜変形挙動の変化について考察し, 以下の結果を得た .

1. 硝子体手術前後の角膜変形挙動を比較すると, 角膜中心部の変位挙動に明確な差が見られ, この差か眼球楕 円変形によって明快に説明できることを示した 。

2. 角膜中心部と周辺部との変位の差が眼球内力学特性を評価する新たな力学的指標になり得る可能性があるこ とを示した。

なお, 本研究は東北大学倫理委員会承認 (承認番号 : 2012-1-175) を受け，患者からインフォームドコンセントを 得たのちに行ったことを付記しておく．

謝 辞

本研究は, 科学研究費基盤 $\mathrm{A}(\mathrm{A} 212460430)\ulcorner$ 角膜剛性と眼圧剛性の分離」の研究費により行われたものである ことを付記しておく .

文献

（1）松浦豊明, 丸岡真治, 川崎健輔, 原嘉昭, 安中雅彦, 児玉亮, “ハイドロゲルを用いた人工硝子体の研究”, Journal of Nara Medical Association, Vol.54, No.3 (2003), pp.147 - 159.

（2）清水昊幸，丸尾敏夫，大島健司，小室三郎”“ 眼科手術書＼cjkstart第 4 巻＼cjkstart硝子体”，金原出版, (1996), pp. 9-12.

(3) 三島濟一，塚原勇，植村恭夫，高久功，松井瑞夫，金原秀雄 “ 眼科 MOOK 硝子体”，金原出版, Vol. 2, (1985), pp. 1-65.

（4）山内愛造, 松沢康夫, 原嘉昭, 神谷貞義, 西岡啓介, 西信元嗣, 中尾主一" “白色家鬼硝子体における PVA 橋かけ含水ゲ ルの挙動 (3) ” , 眼紀, Vol. 30, (1979), pp. 385-389.

(5) Boettner E.A. and Wolter J.R. " Transmission of the ocular madia " , Investigative Opthalmology \& Visual Science, Vol. 1, (1962), pp. 776-783.

(6) Swann D.A. and Constable I.J. "' Vistreous structure. Role of hyaluronate ", Investigative Opthalmology \& Visual Science, Vol. 11, (1972), pp. 164-168.

(7) 平戶孝明 “ 白内障手術と硝子体手術の現状”, 医器学, Vol. 69, No. 11, (1999).

(8) 眼科 Surgeons の会“" 網膜剥離の手術＼cjkstart確実な復位をめざして”，医学書院, Vol. 2, (1996), pp. 1-4.

（9）岩田修造＂“硝子体液化に関する生化学的考察”，日眼誌, Vol. 85, (1981), pp. 1965-1974.

(10) 西出忠之, “水晶体温存硝子体手術における周辺硝子体切除”, Nippon Ganka Gakkai Zasshi, Vol. 95, (1991), pp. 869-872.

(11）日本アルコン株式会社“, ビーエスエスプラス眼灌流液 0.0184 \%”,http://www.alcon.co.jp/hcp/pharmaceutical/product/hssplus.html, (参照日 2013 年 1 月 23 日).

(12) 金子真, Roland Kempf, 栗田雄一, 飯田義親, 石井抱, 三嶋弘, 塚本秀利, 杉本栄一郎, “高速非侵襲計測による生体眼エイジン グ効果の発見”, 計測自動制御学会論文集, Vol.42, No.10 (2006), pp.1093 - 1099.

(13) Yoshiaki, K., Makoto, K., Hideki, M., Joji, T., Kenji, Y. and Junko, T., "Corneal displacement during tonometry with a noncontact tonometer" Jpn J Ophthalmol, Vol.56, No.3 (2012), pp.273 - 279.

（14）金子真，德田寛一，飯田義親，栗田雄一, R. Kempf，川原知洋，石井抱，河野進，三嶋弘，塚本秀利，杉本栄一郎, “眼剛 性センシング”, 計測自動制御学会論文集, Vol. 42, No. 2 (2006), pp.103-110.

(15) 金子真, R. Kempf, 栗田雄一, 飯田義親, 奥出純平, 三嶋弘, 塚本秀利, 杉本栄一郎, “空気噴流方式眼圧計で角膜变形遅 れ特性が起こるメカニズムの解明”, 計測自動制御学会論文集, Vol. 43, No. 2 (2007), pp. 78-84.

(16) Yuichi, K., Roland, K., Yoshichika, I., Jumpei, O., Makoto, K., Hiromu, K. M., Hidetoshi, T., Eiichiro, S., Seiki, K., Ken, K. and Yoshiaki, K.," Contact Based Stiffness Sensing of Human Eye ” , IEEE Transactions on Biomedical Engineering, Vol. 55, No. 2 (2008), pp. 739 - 745.

(17) 森山無価, 大野京子,“近視と後部ぶ゙どう腫” , Japanese Journal of Ophthalmic Surgery, Vol. 25, No. 3 (2012), pp. 327 - 332. 
(18) 東京医科歯科大学 “" 眼科学教室 強度近視外来”, htt $p: / /$ tmdu - ganka.jp/index.php/annai/senmon 2 , (参照日 2013 年 1 月 23 日).

(19) ミツイ眼科医院“"ひとみつうしん”, http://www.hitomi-news.com/glaucoma/hitomi213.html, (参照日 2012 年 10 月 11 日).

（20）三島濟一，塚原勇，植村恭夫“" 緑内障の診断ガイド”，金原出版, (1989), pp. 22-25. 